\title{
Disassembly of the fruit cell wall by the ripening-associated polygalacturonase and expansin influences tomato cracking
}

Fangling Jiang ${ }^{1,2}$, Alfonso Lopez ${ }^{2}$, Shinjae Jeon ${ }^{2,3}$, Sergio Tonetto de Freitas², Qinghui $\mathrm{Yu}^{2,4}$, Zhen $\mathrm{Wu}^{1}$, John M. Labavitch², Shengke Tian ${ }^{2,5}$, Ann L. T. Powell ${ }^{2}$ and Elizabeth Mitcham²

\begin{abstract}
Fruit cracking is an important problem in horticultural crop production. Polygalacturonase (SIPG) and expansin (SIEXP1) proteins cooperatively disassemble the polysaccharide network of tomato fruit cell walls during ripening and thereby, enable softening. A Golden 2-like (GLK2) transcription factor, SIGLK2 regulates unripe fruit chloroplast development and results in elevated soluble solids and carotenoids in ripe fruit. To determine whether SIPG, SIEXP1, or SIGLK2 influence the rate of tomato fruit cracking, the incidence of fruit epidermal cracking was compared between wild-type, Ailsa Craig (WT) and fruit with suppressed SIPG and SIEXP1 expression (pg/exp) or expressing a truncated nonfunctional Slglk2 (g/k2). Treating plants with exogenous ABA increases xylemic flow into fruit. Our results showed that ABA treatment of tomato plants greatly increased cracking of fruit from WT and glk2 mutant, but not from pg/exp genotypes. The $\mathrm{pg} / \exp$ fruit were firmer, had higher total soluble solids, denser cell walls and thicker cuticles than fruit of the other genotypes. Fruit from the ABA treated pg/exp fruit had cell walls with less water-soluble and more ionically and covalently-bound pectins than fruit from the other lines, demonstrating that ripening-related disassembly of the fruit cell wall, but not elimination of SIGLK2, influences cracking. Cracking incidence was significantly correlated with cell wall and wax thickness, and the content of cell wall protopectin and cellulose, but not with $\mathrm{Ca}^{2+}$ content.
\end{abstract}

\section{Introduction}

Cracking of the epidermis of harvested fruit destroys the appearance and increases the susceptibility of fruit to infections by opportunistic pathogens. Fruit with cracks are not marketable, and, therefore, have reduced economic value. Fissures of the fruit epidermis often occur prior to harvest, but can also occur after harvest, depending on storage and environmental conditions ${ }^{1,2}$. The predisposition to form cracks has been correlated with heredity, various fruit traits (shape, size, firmness, strength and components of pericarp, anatomical

Correspondence: Ann L. T. Powell (alpowell@ucdavis.edu) or Elizabeth. Mitcham (ejmitcham@ucdavis.edu)

'Department of Horticulture, Nanjing Agricultural University, Nanjing 210095, China

${ }^{2}$ Department of Plant Sciences, University of California, Davis 95616, USA

Full list of author information is available at the end of the article. structure, water absorbing capacity of the pericarp, number and distribution of stomates, growth period) and external causes, such as cultivation practices (irrigation, nutrition, hormone applications) and growing environment (humidity, temperature, wind, and light) ${ }^{1,3-10}$. Many researchers have attributed cracking predisposition to the thickness of the fruit's cuticular layer adjacent to the epidermal and sub-epidermal cells ${ }^{3,11-14}$. Cracking has also been linked to the loss of flesh firmness and cell wall integrity $^{15,16}$. Fruit that are susceptible to cracking often have high levels of soluble solids and produce juice with elevated concentrations of osmotically active compounds ${ }^{17}$.

As fruit ripen, there is a dramatic increase in their tendency to $\operatorname{crack}^{13,18}$. The production of large, uncracked, ripe fruit in cultivars with thin skins and high soluble solids has proven to be an unmet challenge. The

\section{(c) The Author(s) 2019}

(c) (i) Open Access This article is licensed under a Creative Commons Attribution 4.0 International License, which permits use, sharing, adaptation, distribution and reproduction c. in any medium or format, as long as you give appropriate credit to the original author(s) and the source, provide a link to the Creative Commons license, and indicate if changes were made. The images or other third party material in this article are included in the article's Creative Commons license, unless indicated otherwise in a credit line to the material. If material is not included in the article's Creative Commons license and your intended use is not permitted by statutory regulation or exceeds the permitted use, you will need to obtain permission directly from the copyright holder. To view a copy of this license, visit http://creativecommons.org/licenses/by/4.0/. 
complexity and structural plasticity of the ripening process are challenges for approaches designed to understand the relationship between ripening-associated softening, sugar accumulation and cracking.

Considerable reductions in the incidence and degree of fruit cracking may be achieved by changing cultural or postharvest practices ${ }^{3,19}$. Consistent watering or exogenous applications of boron, calcium and/or growth promoters, such as $\mathrm{GA}_{3}$, can reduce cracking. Applications of calcium and boron strengthen the linkages between polysaccharides in the cell wall, increasing firmness ${ }^{19,20}$. Applications of $\mathrm{GA}_{3}$ likely decrease cracking because this treatment increases the deposition of cuticular material in the epidermis and makes it more elastic ${ }^{21,22}$. Treating plants with abscisic acid (ABA) increases water movement into and promotes enlargement of the fruit. ABA treatment also increases the tendency of fruit to $\mathrm{crack}^{23}$. Application of ABA to "Cabernet Sauvignon" grape berries promotes ripening and the expression of PG1 and proline-rich cell wall protein genes, typically expressed during ripening ${ }^{24}$.

Cracking in tomato (Solanum lycopersicum) fruit most commonly begins as they ripen. During ripening, cell wall modifying proteins, including polygalacturonases (PGs) and expansins (EXPs), cooperatively disassemble wall polysaccharide networks and, thereby, contribute to the softening of fruit. Differences in cell wall structure between varieties and between unripe and ripe fruit could be an important factor in fruit tendency to crack.

Quantitative and qualitative changes in the sugars in ripe fruit could influence water potential and also contribute to the tendency of the fruit to crack. Overexpression of a Golden 2-like (GLK2) transcription factor, SlGLK2, in tomato enhances chloroplast elaboration and photosynthesis gene expression in developing fruit, and results in ripe fruit with elevated soluble solids content $^{25,26}$.

It is desirable to breed or select for varieties whose fruit resist cracking under diverse environmental conditions without hormone treatments. Therefore, we investigated whether reducing the simultaneous expression of SIPG and SlEXP1 genes affects the tendency of fruit to crack. We were also interested to observe cracking of tomato lines with functional or non-functional forms of SlGLK2 to explore the contributions of solutes and sugars to the fruit's predisposition to form cracks. ABA was used as a tool to enhance cracking incidence of the tomato fruit.

\section{Materials and methods Plant material}

A preliminary experiment was conducted in 2012, followed by a similar but more extensive experiment in 2013 with 3 genotypes. The Alisa Craig S. lycopersicum cultivar (hereafter WT) (LA3736) expresses functional SlPG, SIEXP1 and SlGLK2 genes. The transgenic line, pg/exp, has suppressed ripe fruit expression of both SlPG and SIEXP1. It was obtained by crossing homozygous AC SIPG-suppressed and SIEXP1-suppressed lines. Suppression of SIPG or SIEXP1 alone did not significantly enhance fruit firmness. However, fruits with suppressed expression of both genes were significantly firmer throughout ripening with a long-term storage and more viscous juice than control fruits ${ }^{27}$. The monogenic $u / u$ mutant of AC, "Craigella" (LA3247, hereafter glk2), contains a mutation in SlGLK2 that results in a truncated and, therefore, nonfunctional $g l k 2(u)$ protein $^{25}$.

In the 2012 experiment, plants of the $p g / \exp$ and $g l k 2$ genotypes were grown from 15 December 2011 to 3 May 2012 in greenhouses at the University of California, Davis. Prior to germination, seeds were soaked for $3 \mathrm{~h}$ in water and for $30 \mathrm{~min}$ in a $10 \%$ solution of bleach to reduce potential viral contamination, then washed 3 times with deionized water and placed into Petri dishes with $7 \mathrm{~mL}$ $30 \mu \mathrm{M} \mathrm{GA}{ }_{3}$ for 2 days at $4{ }^{\circ} \mathrm{C}$. Subsequently, seeds were germinated in a growth chamber at $25^{\circ} \mathrm{C}$. Seedlings were transplanted and moved to the greenhouse on 16 January. There were 64 plants of each genotype ( $p g / \exp$ or $g l k 2$ ) subdivided into two treatments (water or $\mathrm{ABA}$ ) and 4 replications with 8 single plant replicates per treatment. Seedlings were grown in $9.5-\mathrm{L}$ pots containing $33.3 \%$ each peat, sand, and red wood compost with $2.6 \mathrm{~kg}$ dolomite lime $\mathrm{m}^{-3}$. The plants were irrigated twice per day with $350 \mathrm{~mL}$ of UC Davis nutrient solution containing $\mathrm{NH}_{4}{ }^{+}(6$ ppm), $\mathrm{NO}_{3}{ }^{-}$(96 ppm), $\mathrm{H}_{2} \mathrm{PO}_{4}{ }^{-}$(26 ppm), $\mathrm{K}^{+}$(124 ppm), $\mathrm{Ca}^{2+}$ (90 ppm), $\mathrm{Mg}^{2+}$ (24 ppm), $\mathrm{SO}_{4}{ }^{2-}$ (16 ppm), Fe (1.6 ppm), Mn (0.27 ppm), B (0.25 ppm), Cu (0.16 ppm), Zn $(0.12 \mathrm{ppm})$ and Mo $(0.016 \mathrm{ppm})$. Plants were pollinated on 8 March 2012, and were topped on 15 March 2012 when they had 2 clusters of flowers. On 18 April, ABA and control spray treatments began. The plants were sprayed $1 \times$ per week for 3 weeks with a backpack applicator until the plants were completely covered with a solution containing deionized water (control) or $0.5 \mathrm{mg}$ $\mathrm{L}^{-1}$ ABA (Valent Biosciences, Clovis, CA); each solution also contained $0.5 \mathrm{~mL} \mathrm{~L}^{-1}$ polysorbate 20 (Tween 20 , Fisher Scientific, Fair Lawn, NJ) as a surfactant. The cracking fruits were counted and cracking rates were calculated on 26 April. The other characteristics of the fruits were then analyzed.

In 2013, WT, $p g / e x p$ and $g l k 2$ plants were grown from 17 December 2012 to 6 May 2013 in greenhouses. Seed germination protocols were like those used in 2012 . Seedlings were transplanted into pots in the greenhouse on 14 January. There were 192 plants in total with 64 plants for each genotype, as in 2012. In the greenhouse, passive ventilation was used to maintain a relative humidity of $26.1-27.4 \%$. The average temperature ranged 
from 21.5 to $22.7^{\circ} \mathrm{C}$ with minimum of $12.8^{\circ} \mathrm{C}$ and maximum of $35.0^{\circ} \mathrm{C}$. Cultivation practices were the same as in 2012, although the irrigation schedule was modified due to growth periods. Plants were initially irrigated twice per day with $350 \mathrm{~mL}$ of UC Davis nutrient solution. The irrigation frequency was increased to 5 times per day with $200 \mathrm{~mL}$ at full bloom (4 March). It was then increased to 8 times per day the week after pollination (18 March). Irrigation started $1 \mathrm{~h}$ before sunrise and finished $1 \mathrm{~h}$ after sunset. Three days before harvest, the irrigation frequency was adjusted to one time per day with $4800 \mathrm{~mL}$ water (starting at 11:00 am) to further enhance cracking. Plants were topped on 28 February when they had 2 clusters of flowers and were pollinated on 1, 4, 8, and 11 March. On $18 \mathrm{March}$, the spray treatments with water or ABA began, applied 3 times per week for 7 weeks, until 22 April. Tomato cracking rate, firmness, total soluble solids (TSS) and titratable acidity (TA) were analyzed on 30 April. The fruit materials for other analyses were preserved until the next day and then analyzed.

Tomato fruit size and expansion rate during development

In 2012, fruit diameters were measured using a caliper on 26 April. In 2013, fruit that were approximately equal in size at the start of treatment application (diameters 18.4 minimum to $19.1 \mathrm{~mm}$ maximum) were selected for analysis and tagged. The diameters of 12 fruits per treatment and genotype were measured every 2-3 days, beginning when the first treatment was applied and continuing until the fruit were ripe. The expansion rate was calculated by dividing the increase in diameter in 2 or 3 days by the number of growth days.

$$
\text { Expansion rate }=\frac{\text { The increase of diameter in } 2 \text { or } 3 \text { days }}{\text { growth day }}
$$

\section{Stomatal conductance}

Stomatal conductance was measured on 19 April (1 d after the first spray treatment application) in 2012 and on 21 and 28 March in 2013 (3 and 10 days after the first treatment) in 2 fully expanded leaves located on opposite sides of each plant (fifth to seventh basipetally located leaves). Measurements were made between 1:00 and 3:00 p.m. with a steady-state porometer (LI-1600, LI-COR Biotechnology, Lincoln, NE).

\section{Percent cracking}

In 2012, the incidence of cracking was determined visually on 26 April in all full-sized fruit which were then categorized into different ripeness stages from the same or different clusters based on external fruit color and tagged date. In 2013, the incidence of cracking of fruit at the MG, turning and RR stages were recorded on 30 April.

\section{Measurement of fruit firmness, total soluble solids, and titratable acidity}

In 2012, fruit firmness was measured on turning, pink and RR fruit, which had no cracks on 2 May. In 2013, fruit firmness was measured on fruit with no cracks at the MG and RR stages on 30 April. In both years, firmness was measured by compressing the fruit at the equator using a $51 \mathrm{~mm}$ flat stainless steel probe (test speed $2 \mathrm{~mm} \mathrm{~s}^{-1}$ ) (TaXT2i Texture Analyzer; Texture Technologies). In 2012, fruit were compressed $5 \mathrm{~mm}$ and in 2013 fruit were compressed $2 \mathrm{~mm}$.

TSS and TA were measured on RR fruit on 26 April in 2012. In 2013, TSS and TA were measured in cracked RR fruit and uncracked fruit at the MG and RR stages on 30 April. For each genotype, treatment, and phenotype, four fruit were cut in half from peduncle to blossom-end, creating 8 replicated samples. The samples were squeezed and the juice was filtered through 2 layers of cheesecloth. A few drops of juice were used to measure TSS content by refractometry (Reichert AR6 series). Four grams of juice diluted in $20 \mathrm{~mL}$ deionized water were titrated (Radiometer Titralab Tim 850 titration manager and SAC80 sample charger) to determine TA based on citric acid equivalents.

\section{Isolation of cell walls}

The preparation of total cell walls (i.e., alcohol-insoluble residue, AIR) followed the protocols of Vicente ${ }^{28}$; the AIR was dried and was identified as the total cell wall fraction of ground tissue. Samples of approximately $15 \mathrm{~g}$ of exocarp (collected from peduncle to blossom-end portions on the fruit) and mesocarp (collected from peduncle to blossom-end portions), peduncle (peduncle proximal half, including exocarp and mesocarp) or blossom-end (blossom-end half, including exocarp and mesocarp) tissues from fruit harvested RR with no cracks were used for cell wall extractions.

\section{Pectin and cellulose contents}

Fractions enriched for pectic polymers of the isolated cell wall preparations were sequentially extracted from AIR. From $200 \mathrm{mg}$ of AIR, water soluble pectins (WSP, fraction mainly pectins with no strong bonds to the rest of the cell wall), chelator soluble pectins (CSP, fraction of pectins that were ionically bound into the wall via linkages to $\mathrm{Ca}^{2+}$ and are soluble in the chelator trans-1, 2-diaminocyclohexane- $N, N, N^{\prime}, N^{\prime}$-tetraacetic acid (CDTA)) and sodium carbonate-soluble pectins (SSP, pectin extracted using $50 \mathrm{mM} \mathrm{Na} \mathrm{CO}_{3}$, a fraction containing mainly pectins covalently bound by ester linkages into the cell wall) were prepared, as described in Vice$\mathrm{nte}^{28}$. Cellulose was measured following the protocols of Vicente too ${ }^{28}$. 


\section{Calcium content}

The dried AIR samples of the tomato fruit analyzed in 2013 were weighed and ground to a uniform powder. The calcium content of $200 \mathrm{mg}$ of the replicated AIR preparations was determined by inductively coupled plasma optical emission spectrometry (Optima 2100 DV, Perkin Elmer, America $)^{29}$.

\section{Preparation of plant materials for microscopy}

Samples of RR fruit were fixed for microscopic evaluation. Sections with exocarp and mesocarp ( $1 \mathrm{~mm} \times$ $1 \mathrm{~mm} \times 2 \mathrm{~mm}$ ) were cut from the peduncle half of the fruit using razor blades and the tissues were immediately fixed in PEM buffer (50 mM PIPES, $5 \mathrm{mM}$ EGTA, and $5 \mathrm{mM} \mathrm{MgSO}_{4}, \mathrm{pH}$ 6.9) containing $4 \%$ (w/v) paraformaldehyde under vacuum ( $1 \mathrm{~h}$ at room temperature). Tissues were dehydrated through a graded ethanol series, and then infiltrated with LR White resin (Sigma-Aldrich, St. Louis, MO, USA) and $95 \%$ ethanol $(1: 1, v / v)$ for $40 \mathrm{~min}$, followed by $100 \%$ resin for $40 \mathrm{~min}$, and then the samples were held in $100 \%$ resin overnight on a rotator at room temperature. The samples were polymerized in gelatin capsules for 2 days at 0 to $-20^{\circ} \mathrm{C}$ in a cryo chamber. Sections were cut to a thickness of $1 \mu \mathrm{m}$ using a glass knife on an Ultra cut microtome (Leica), and then collected on multiwell slides (ICN Biomedicals) filled with water.

\section{Immunofluorescence microscopy}

For reactions with the JIM5 and JIM7 antibodies ${ }^{30,31}$, fruit tissue sections that had been fixed and embedded were incubated in $1 \times$ phosphate buffered saline (PBS, pH7.2, Sigma-Aldrich) with $0.05 \%$ Tween-20 containing $5 \%(\mathrm{w} / \mathrm{v})$ nonfat milk protein (MP/PBS, blocking solution) for $1 \mathrm{~h}$. The blocking solution was removed and one drop (approximately $30 \mu \mathrm{L}$ ) of primary antibody (e.g., JIM5) diluted 1:10 in MP/PBS was added to the tissue and incubated overnight. Afterwards, samples were washed in MP/PBS (10 min) twice and incubated with a 100-fold dilution of FITC-conjugated rabbit antirat IgG (whole molecule; batch no. 078K4833, SigmaAldrich) in MP/PBS for $1 \mathrm{~h}$ in darkness. After washing in PBS twice for $5 \mathrm{~min}$ each to remove the excess second antibody, the sections were mounted in an anti-photobleaching medium (100 mM Tris, $\mathrm{pH}$ 9.2, 50\% glycerol and $1 \mathrm{mg} \mathrm{mL} \mathrm{m}^{-1} p$-phenylenediamine), before sections were examined under blue light $(488 \mathrm{~nm})$ using an Olympus BH2 microscope. The samples of each genotype were divided into four groups: one for incubation with a monoclonal cell wall antibody (primary antibody JIM5 or JIM7) and the corresponding FITC-conjugated secondary antibody; the other three (with only primary, secondary or no antibody) for three types of experimental controls. Images were all obtained following exposure for exactly $3 \mathrm{~s}$ to guarantee that any differences observed were caused by treatment or genotypes, rather than by differing exposure times. The relative fluorescent intensity from three slices was measured from three visible regions in each slice for each treatment using the ImageJ software.

\section{Transmission electron microscopy}

Samples were prepared according to Zhang ${ }^{32}$. Ultrathin fixed and embedded fruit tissue sections were examined with a Hitachi-7650 transmission electron microscope. The cell wall thickness from 5 slices was measured from six visible regions in each slice for each treatment.

\section{Light microscopic observation}

For observation of the cuticular wax layer, toluidine blue $\mathrm{O}$ (TBO) staining, fresh fruit sections were incubated in a solution of $1 \%(\mathrm{w} / \mathrm{v})$ TBO containing $1 \%(\mathrm{w} / \mathrm{v})$ sodium borate for $5 \mathrm{~min}$, washed in water $(3 \mathrm{~min})$, mounted in glycerol, and observed using an Olympus $\mathrm{BH} 2$ microscope. TBO stains waxes preferentially. The thickness of the cuticular wax was determined from 5 slices and 6 views in each slice for each treatment.

\section{Data analysis}

Analysis of variance (ANOVA) to determine differences in fruit characteristics between the genetic materials and treatments, and correlations between fruit parameters and cracking incidence was determined using statistical product and service solutions (SPSS) 16.0 (SPSS Inc. Chicago, IL, USA).

\section{Results}

Tomato fruit size and expansion rate during development

The size and the rates of expansion of the diameters of the fruit while attached to the plant were measured during development to determine whether the genotypes or the ABA treatments altered the fruit characteristics. In 2012, there was no difference in the size of the $p g / \exp$ fruit $(52.7 \mathrm{~mm}$ in ABA treated plants and $52.2 \mathrm{~mm}$ in water treated plants) compared to the $g l k 2$ mutant fruit $(54.1 \mathrm{~mm}$ in ABA treated plants and $52.8 \mathrm{~mm}$ in water treated plants). In 2013, the initial fruit diameters (day 1) were similar $(18.6 \mathrm{~mm}, 18.6 \mathrm{~mm}$ and $18.4 \mathrm{~mm}$, for the WT, $g l k 2$ mutant and $p g / \exp$ genotypes, respectively). Fruit on plants treated with water (control), showed no significant differences between genotypes (Fig. 1). After spraying with ABA for 26 days, the $p g / \exp$ fruit averaged $50.1 \mathrm{~mm}$ in diameter; and the diameters of the WT $(44.4 \mathrm{~mm})$ and $g l k 2$ mutant $(42.3 \mathrm{~mm})$ fruit were clearly smaller $(P<0.05)$, and the rate of expansion of $p g / \exp$ (around day 3 and 20) was the highest among the 3 genotypes. 


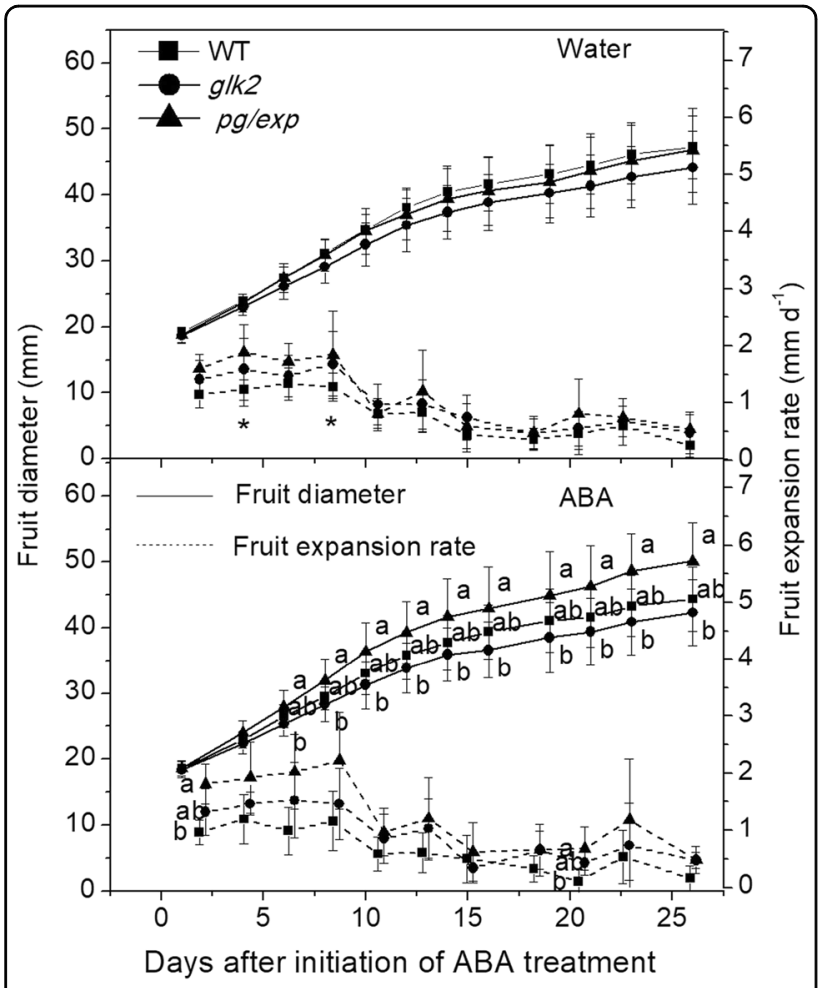

Fig. 1 Increase in diameter (solid line) and expansion rate (dashed line) of WT, $g / k 2$, and pg/exp ripe tomato fruit following initiation of water and $A B A$ treatment at $18 \mathrm{~mm}$ average fruit size. WT indicates wild type Alisa Craig; glk2 indicates a nonfunctional Slglk2 mutant; and pg/exp indicates transgenic fruit with suppressed SIPG and SIEXP1 expression, the same as below. Different lowercase letters indicate a significant difference between genotypes $(<0.05)$. Differences between the water and ABA treatment within the same genotype were determined with a $T$ test. Asterisk $(*)$ indicates a significant difference between water and ABA treatments $(<0.05)$

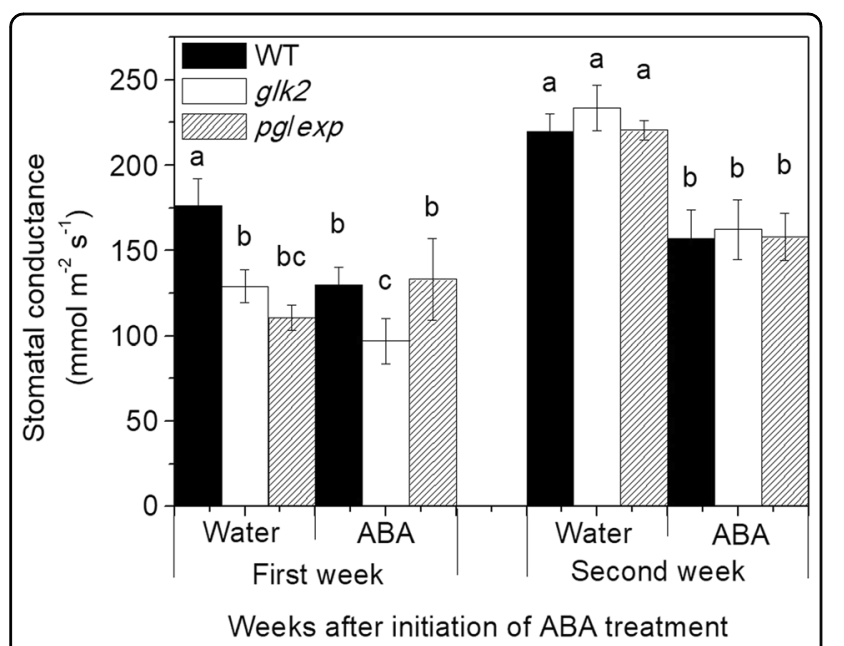

Fig. 2 Stomatal conductance of WT, $g / k 2$, and $p g / \exp$ tomato fruit following initiation of water and ABA treatment at $18 \mathrm{~mm}$ average fruit size. Different lowercase letters indicate a significant difference in stomatal conductance in the same week $(<0.05)$

\section{Stomatal conductance}

In 2012, stomatal conductance for $p g / \exp$ and $g l k 2$ mutant was 171.4 and $183.3 \mathrm{mmol} \mathrm{m}^{-2} \mathrm{~s}^{-1}$, respectively, in water treated plants, and conductance decreased to 53.9 and $31.4 \mathrm{mmol} \mathrm{m}^{-2} \mathrm{~s}^{-1}$ in ABA treated plants. In 2013, results were similar. Spraying plants of all genotypes with ABA decreased stomatal conductance for up to two weeks of treatments $(P<0.05)$ (Fig. 2), but no further decrease was observed compared to water-sprayed plants (data not shown). There were no consistent differences in stomatal conductance between genotypes, although in the first week of spraying, leaves from WT plants had slightly higher stomatal conductance than $g l k 2$ mutant leaves $(P<$ 0.05).

\section{Percent cracking}

The incidence of cracking, as evidenced by visible fissures in the epidermis, increased as fruit ripened from MG to turning to RR stages in 2012 and 2013. In both years, no MG fruit were cracked and less than $5 \%$ of turning fruit were cracked, regardless of the treatment (data not shown). In 2012, ABA treatment increased the incidence of cracking of the RR glk2 mutant tomatoes (30.2\% of ABA treated plants compared to $20 \%$ of water treated plants), but not the $p g / \exp$ tomatoes $(13.1 \%$ in ABA treated plants and $12.1 \%$ in water treated plants). Similarly, in 2013, treatment of the plant with ABA increased the incidence of cracking of RR fruit of the WT and $g l k 2$ mutant genotypes, but not of the $p g / \exp$ genotype (Fig. 3).

\section{Fruit firmness, total soluble solids, and titratable acidity}

To test the hypothesis that fruit texture and the resistance to tension indicate the tendency of fruit to crack, fruit firmness was measured. In 2012, firmness decreased as the fruit ripened and the $p g / \exp$ fruit were firmer than glk2 mutant. The firmness of the non-cracked, ABA treated $p g / \exp$ tomatoes were 1.31, 1.31, and 1.09 times greater than that of the glk2 mutant tomatoes on turning, pink and RR stages, respectively. In 2013, the firmness of MG and RR fruit without cracks was measured on the day of harvest. As in 2012, firmness of MG fruits was greater than RR fruits for each genotype (Table 1$)(P<0.05)$. And the firmness of ABA treated $p g / \exp$ tomatoes were 1.19 and 1.10 times greater than that of the glk2 mutant, and 1.13 and 1.20 times greater than that of the WT fruit on MG and RR stages, respectively (Table 1 ).

In 2012, the $p g / \exp$ fruit had consistently higher TSS (5.90\% in ABA treated and $5.78 \%$ in water treated plants) than the $g l k 2$ mutant $(5.48 \%$ in ABA and $5.10 \%$ in water treated plants). Similar results were observed in 2013 (Table 1). The $p g / \exp$ fruit had consistently higher TSS than the glk2 mutant and WT fruit except for ABAtreated red ripe cracked fruit. The TSS increased in fruit 

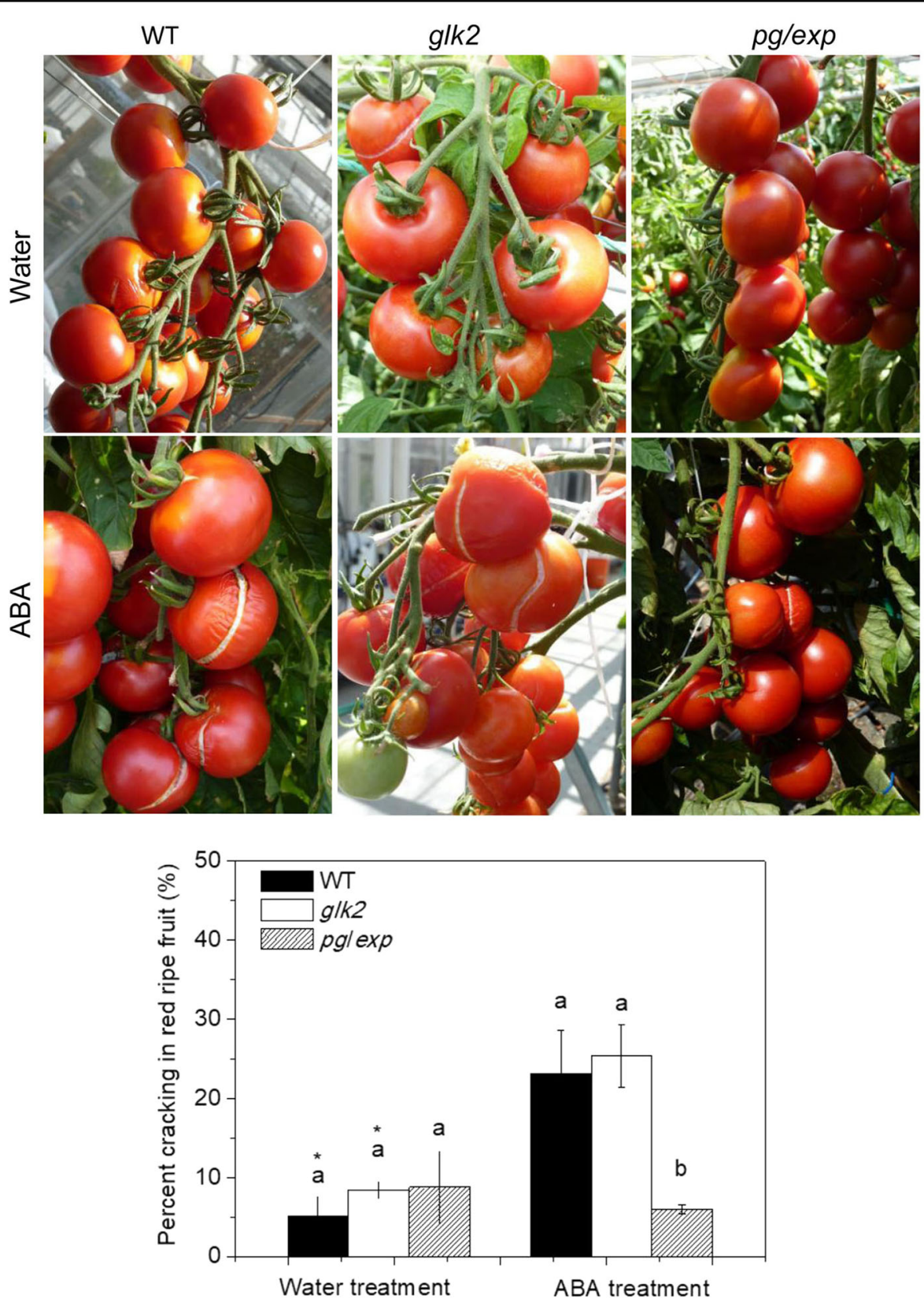

Fig. 3 Percent cracking in red ripe WT, glk2, and pg/exp tomato fruit treated with water or ABA beginning at $18 \mathrm{~mm}$ average fruit size. Different lowercase letters indicate a significant difference between genotypes $(<0.05)$. Difference between the water and $A B A$ treatment within the same genotype were determined with a $T$ test. Asterisk $\left(^{*}\right)$ indicates a significant difference between water and ABA treatments $(<0.05)$. The same as below

of all genotypes as they ripened from MG to RR. Fruit of the same genotype and the same ripeness stage from plants treated with ABA had lower TSS and TA than fruit from plants treated with water. At the MG stage, WT fruit had higher TA than the $g l k 2$ mutant fruit $(P<0.05)$.

\section{Pectin and cellulose contents}

To determine whether differences in the composition of the fruit cell wall polysaccharide fractions could account for differences in fruit cracking among the genotypes, AIRs were prepared from the exocarp, mesocarp, peduncle, and blossom-end portions of the fruit at the RR stage. In this analysis, pectin solubilization is indicated primarily by the proportion of galacturonic acid containing polysaccharides in each fraction. The WSP fraction was reduced in $p g / \exp$ compared to WT and $g l k 2$ mutant fruit in nearly all parts of the fruit except the exocarp and peduncle portions of water treated plants (Fig. 4). The CSPs were greater in the 
Table 1 Total soluble solids, titratable acidity and firmness of mature green, red ripe uncracked and red ripe cracked tomatoes of three genotypes (2013)

\begin{tabular}{|c|c|c|c|c|c|c|c|}
\hline \multirow[t]{2}{*}{ Stage } & \multirow[t]{2}{*}{ Genotypes } & \multicolumn{2}{|c|}{ Total solublesolids (\%) } & \multicolumn{2}{|c|}{ Titratable acidity $\left(\mathrm{g} \mathrm{L}^{-1}\right)$} & \multicolumn{2}{|c|}{ Firmness $(N)$} \\
\hline & & Water & $A B A$ & Water & $A B A$ & Water & $A B A$ \\
\hline \multirow[t]{3}{*}{ Mature green } & WT & $4.82 \mathrm{ab}$ & $4.53 a b$ & $0.93 \mathrm{a}$ & $0.87 \mathrm{a}$ & $6.13 b$ & $6.50 \mathrm{~b}$ \\
\hline & glk2 & $4.49 \mathrm{~b}$ & $4.35 \mathrm{~b}$ & $0.79 \mathrm{~b}$ & $0.70 \mathrm{~b}$ & $6.27 \mathrm{~b}$ & $6.20 \mathrm{ab}$ \\
\hline & pg/exp & $5.15 \mathrm{a}^{\mathrm{a}}$ & $4.61 \mathrm{a}$ & $0.88 \mathrm{ab}$ & $0.83 a b$ & $7.37 \mathrm{a}$ & $7.37 \mathrm{a}$ \\
\hline \multirow[t]{3}{*}{ Red ripe } & WT & $5.68 b^{a}$ & $4.89 \mathrm{~b}$ & $0.51 a^{a}$ & $0.40 \mathrm{a}$ & $1.20 \mathrm{~b}$ & $1.58 \mathrm{~b}$ \\
\hline & $g / k 2$ & $5.16 b^{a}$ & $4.80 \mathrm{~b}$ & $0.41 \mathrm{a}$ & $0.37 a$ & $1.72 \mathrm{ab}$ & $1.73 \mathrm{ab}$ \\
\hline & pg/exp & $6.46 \mathrm{a}^{\mathrm{a}}$ & $5.58 \mathrm{a}$ & $0.50 a^{a}$ & $0.40 \mathrm{a}$ & $2.03 \mathrm{a}$ & $1.90 \mathrm{a}$ \\
\hline \multirow[t]{3}{*}{ Red cracked } & WT & $5.45 \mathrm{~b}$ & $4.90 \mathrm{a}$ & $0.50 a^{a}$ & $0.44 \mathrm{a}$ & - & - \\
\hline & $g / k 2$ & $4.97 \mathrm{~b}$ & $5.01 \mathrm{a}$ & $0.45 \mathrm{a}$ & $0.47 \mathrm{a}$ & - & - \\
\hline & pg/exp & $6.35 a^{a}$ & $5.58 \mathrm{a}$ & $0.45 \mathrm{a}$ & $0.42 \mathrm{a}$ & - & - \\
\hline
\end{tabular}

Different lowercase letters indicate a significant difference between genotypes within a stage and treatment $($ water or $A B A)(P<0.05)$

${ }^{\mathrm{a}}$ Indicates a significant difference between water and ABA treatments $(P<0.05)$

mesocarp portion of the ripened $p g / \exp$ fruit than the WT fruit in both water and ABA treatments, and was greater in the peducle-end and blossom-end tissues of $p g / \exp$ fruit compared to WT after water treatment. The SSP fractions were also more abundant in $p g / \exp$ than in WT and $g l k 2$ mutant fruit in the exocarp of both water and ABA treated fruits as well as in the mesocarp and peducle-end water treated fruits. But in some cases, the WT fruit had a higher proportion of SSP (Fig. 4). And ABA-treated fruits had less WSP, SSP, and total pectin than did water treated fruits in the mesocarp and blossom-end portion of fruits $(P<0.05)$ (Fig. 4).

The cellulose content of the extracted cell walls was higher in the mesocarp portion of $p g / \exp$ fruit than in WT and $g l k 2$ mutant fruit $(P<0.05)$ (Fig. 5).

\section{Calcium content in fruit and the cell walls of fruit}

The $\mathrm{Ca}^{2+}$ content of $p g / \exp$ fruit and their cell walls was lower than that of WT fruit, whether the plants were treated with water or with $\mathrm{ABA}$, and also lower than that of $g l k 2$ mutant fruit from water treated plants. The $\mathrm{Ca}^{2+}$ content of WT and $p g / \exp$ fruit treated with ABA was higher compared to fruit from plants treated with water, while the $\mathrm{Ca}^{2+}$ content in $g l k 2$ mutant fruit from plants treated with ABA was lower than that of fruit from watertreated plants $(P<0.05)$ (Table 2$)$.

\section{Pectin esterification and cracking}

Indirect immunofluorescence microscopy was used to detect two classes of pectins in microscopic sections of RR tomato fruit. The monoclonal antibody, JIM5, identifies pectin with low levels of esterification and JIM7, detects highly esterified pectin ${ }^{30,33}$. The JIM5 antibody weakly recognized epitopes in WT and glk2 mutant fruit cell walls, but there was even less JIM5 recognition of homogalacturonan components in $p g / \exp$ fruit, regardless of treatment (Fig. 6a-f, m, n). These differences in antibody binding were particularly apparent in the mesocarp portion of the fruit. The JIM7 antibody strongly recognized esterified pectins in fruit from all genotypes from water treated plants (Fig. $6 \mathrm{~g}-\mathrm{i}$, o, p), but fewer epitopes were seen in fruit from ABA-treated plants (Fig. 6j-l, o, p). However, JIM7 recognized esterified pectins most strongly in $p g / \exp$ and least strongly in WT fruit (Fig. 6g, i, j, l-p).

\section{Cell wall thickness and epidermal waxes}

When examined by electron microscopy, cell walls from RR $p g / \exp$ fruit appeared thicker and denser (Fig. 7c, f) than cell walls of RR WT (Fig. 7a, d) and glk2 (Fig. 7b, e) fruit. The $p g / \exp$ fruit also had a thicker wax layer than the other tested genotypes from plants treated with water (Fig. 8a-c) and ABA (Fig. 8d-f).

\section{Correlation analysis between crack incidence and fruit characteristics}

The correlation analysis illustrated that cracking incidence was significantly associated with stomatal conductance (SC1 $-0.589^{*}$; SC2 $-0.582^{*}$ ), cell wall thickness (CW-thickness $\left.-0.482^{*}\right)$, wax-thickness $\left(-0.497^{*}\right)$, and the content of TSS (MG $-0.509^{*} ; \mathrm{RR}-0.614^{* *}$; RC $\left.-0.472^{*}\right)$, TA (RR $\left.-0.516^{*}\right)$, protopectin (Me-SSP $-0.477^{*}$; Pe-CSP -0.573*; Ex-JIM7P -0.547**; Me-JIM7P $\left.-0.569^{* * *}\right)$, and cellulose (Ex 0.491*; Pe 0.724**; $\left.\mathrm{Bl}-0.495^{*}\right)$ (Table 3). However, cracking incidence was not associated with fruit- $\mathrm{Ca}^{2+}$ or $\mathrm{CW}-\mathrm{Ca}^{2+}$. 


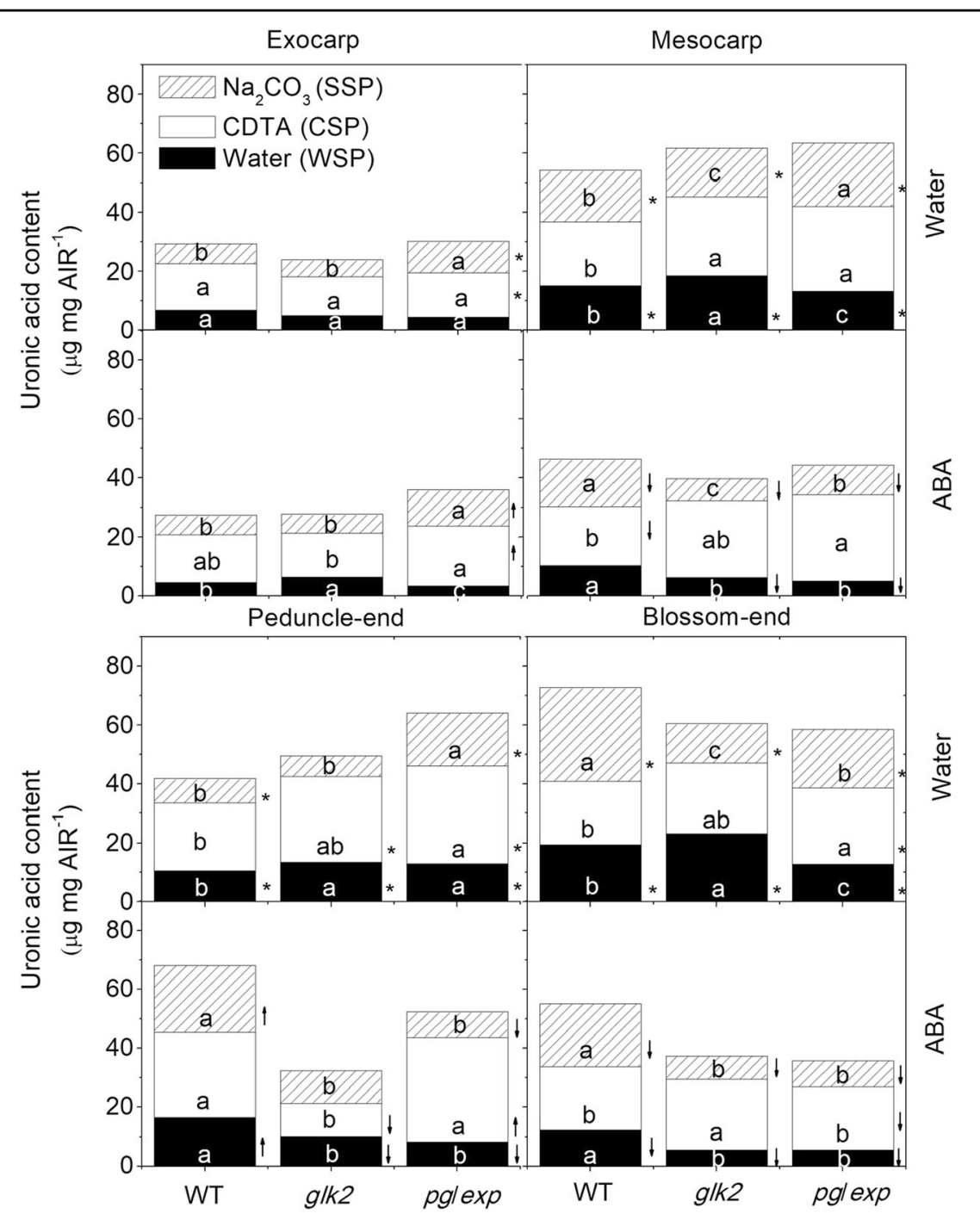

Fig. 4 Water, CDTA, and $\mathrm{Na}_{2} \mathrm{CO}_{3}$-solubilized pectins (WSP, CSP, SSP) as measured by the uronic acid equivalents in alcohol-insoluble residues (AIR) prepared from the exocarp and mesocarp portion of red ripe WT, glk2 and pg/exp tomato plants treated with water or ABA. $\uparrow$ indicated that pectin (WSP, CSP, or SSP) from ABA-treated portion increased compared to water treated portion, $\downarrow$ indicated that pectin (WSP, CSP or SSP) from ABA-treated portion decreased compared to water treated portion

\section{Discussion}

Previous research indicates that heritable resistance to cracking can be identified in some tomato breeding lines. However, no single genetic locus seems to be responsible for inheritance of the fruit cracking trait and many genes may contribute to the phenotype ${ }^{2}$. Many studies point to the involvement of cell wall structure and possibly the cuticle layer in fruit cracking ${ }^{1,34-40}$. As cell wall networks weaken with fruit ripening ${ }^{41,42}$, even as cell turgor falls, resistance to stresses at the fruit surface may require a greater contribution from wax and cuticle layer structures than they can provide; and cell turgor pushing the plasmalemma against the cell wall also creates some stress on the cell wall polysaccharide networks that may be accommodated by the elasticity of the wall "fabric"; this then leading to cracking.

Polysaccharides make up more than $90 \%$ of the mass of the plant cell wall. The pectins are relatively uronic acidrich polymers that are the most structurally complex polysaccharides in plant primary cell walls ${ }^{43,44}$. PG is believed to be responsible for a large part of the HG pectin depolymerization in ripening tomatoes; PG mRNA, protein, and activity accumulate to very high levels late in the ripening of tomato fruit ${ }^{34}$. Brummell reported that suppression of the ripening-related EXP-encoding gene slowed tomato fruit softening early in ripening, and they 
hypothesized that EXP1-mediated relaxation of the wall structure is necessary to allow PG or other enzymes access to polyuronide or other wall substrates ${ }^{38}$.

To investigate how PG and EXP may work collaboratively to affect the susceptibility of tomato fruit to cracking, we investigated differences in cell wall composition as influenced by the $p g / \exp$ genotype in fruit stressed by increased water uptake following treatment with ABA.

Ripening in tomato is accompanied by a shift in pectins from the CSP and SSP to the WSP ${ }^{45}$. The clearest impact of simultaneous suppression of PG and EXP was that the $p g / \exp$ fruit displayed a substantially reduced breakdown of the cell wall pectin network as they proceed through ripening and the fruit soften less than WT fruit ${ }^{46}$. The pectin polymers in ripe fruit of the $p g / \exp$ genotype are bigger than those in ripe WT fruit, and there was more SSP in $p g / \exp$ fruit compared with $\mathrm{WT}^{27,46}$. In our study, the cracking-resistant $p g / \exp$ genotype, had more CSP in the mesocarp portion, and more SSP in the exocarp portion of the fruit. In contrast, there was more WSP in fruit of the WT genotype. This observation suggests that both the exocarp and mesocarp cell walls of $p g / \exp$ fruit

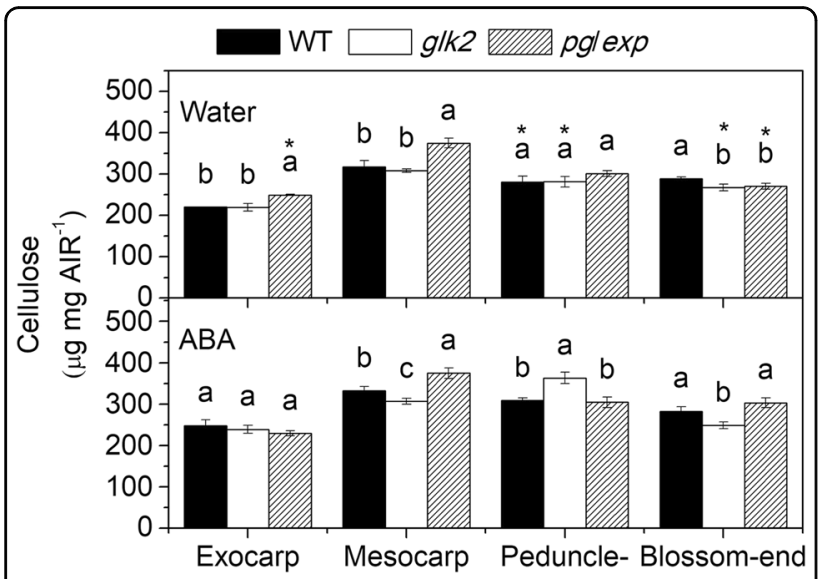

Fig. 5 Cellulose content in the alcohol-insoluble residues (AIR) prepared from the exocarp and mesocarp portion of red ripe WT, glk2, and $p g /$ exp tomato fruit from plants treated with water or $A B A$ were more intact and thus better able to resist internal stresses that are presumed to promote ripe fruit cracking.

The calcium content of the fruit and their cell walls can affect cell wall strength. Pectins with low levels $(<40 \%)$ of methoxyl-esterification can form gels; calcium-ion $\left(\mathrm{Ca}^{2+}\right)$ bridging of unesterified GalA residue carboxyl groups on neighboring HG pectins has been proposed to form "eggbox" structures in the primary cell wall matrix ${ }^{47}$. And the strength of the $\mathrm{Ca}^{2+}$-promoted-gels increases with increasing $\mathrm{Ca}^{2+}$ concentration. In this experiment, the higher $\mathrm{Ca}^{2+}$ level in the AIR from WT fruit than in the AIR from the firmer and less-cracked $p g / \exp$ fruit is somewhat surprising. It is not clear how the AIR's $\mathrm{Ca}^{2+}$ content corresponds with the relative distributions of $\mathrm{Ca}^{2+}$ in the cell wall/apoplast, the cytoplasm and the vacuolar compartments. However, our immunofluorescence microscopy with JIM5 and JIM7 antibodies revealed that $\mathrm{pg} / \exp$ fruit had more highly esterified pectins than WT fruit, indicating less capacity for cell wall binding of $\mathrm{Ca}^{2+}$. In some cases, there is also less $\mathrm{Ca}^{2+}$ in cracking-resistant varieties ${ }^{48}$. We conclude that a ripe fruit with more intact pectins in its primary walls is likely to resist cracking more effectively, as long as a reasonable degree of pectin-pectin bonding (via $\mathrm{Ca}^{2+}$ or other crosslinkages) is retained. The correlation analysis demonstrated that crack rate was associated most significantly with the protopectin and cellulose rather than $\mathrm{Ca}^{2+}$, which confirms this view.

In our study, we used whole-plant sprays of ABA to increase the tendency of tomato fruit to crack. ABA application can decrease stomatal conductance and leaf transpiration, and increases plant water potential ${ }^{49}$, which results in significantly increased xylemic flow into tomato fruit $^{23}$. This xylemic flow also carries more $\mathrm{Ca}^{2+}$ into the fruit as has been reported previously and is evident in the higher $\mathrm{Ca}^{2+}$ levels in both whole fruit and cell walls of ABA treated fruit. The higher incidence of cracking in ABA treated RR tomato fruit was likely due to accumulation of water in the fruit when leaf transpiration was reduced by $A B A$, likely resulting in increases in turgor pressure in the fruit. However, the fruit genotypes showed

Table $2 \mathrm{Ca}^{2+}$ content $\left(\mu \mathrm{g} \mathrm{g}^{-1}\right)$ in fruits and cell wall of fruits of three genotypes treated with water or abscisic acid (ABA)

\begin{tabular}{lllll}
\hline Genotypes & Fruits & & \multicolumn{2}{l}{ Cell wall } \\
\cline { 2 - 3 } & Water & ABA & Water & ABA \\
\hline WT & $10.22 \pm 0.62 b^{a}$ & $14.43 \pm 0.49 a$ & $39.27 \pm 1.46 b^{a}$ & $53.91 \pm 1.50 a$ \\
glk2 & $15.68 \pm 0.11 a^{a}$ & $10.97 \pm 0.15 b$ & $50.03 ; \pm 1.44 a$ & $40.87 \pm 5.47 b$ \\
pg/exp & $9.17 \pm 0.13 c^{a}$ & $9.92 \pm 0.33 c$ & $33.37 \pm 0.86 c^{a}$ & $37.60 \pm 1.61 b$ \\
\hline
\end{tabular}

Differences between the genotypes were determined with a Tukey test. Different lowercase letters indicate a significant difference between genotypes within water or ABA treatment $(<0.05)$. Difference between the water and ABA treatment within the same genotype were tested with a $T$ test

${ }^{a}$ Indicates a significant difference between water and ABA treatments $(<0.05)$ 


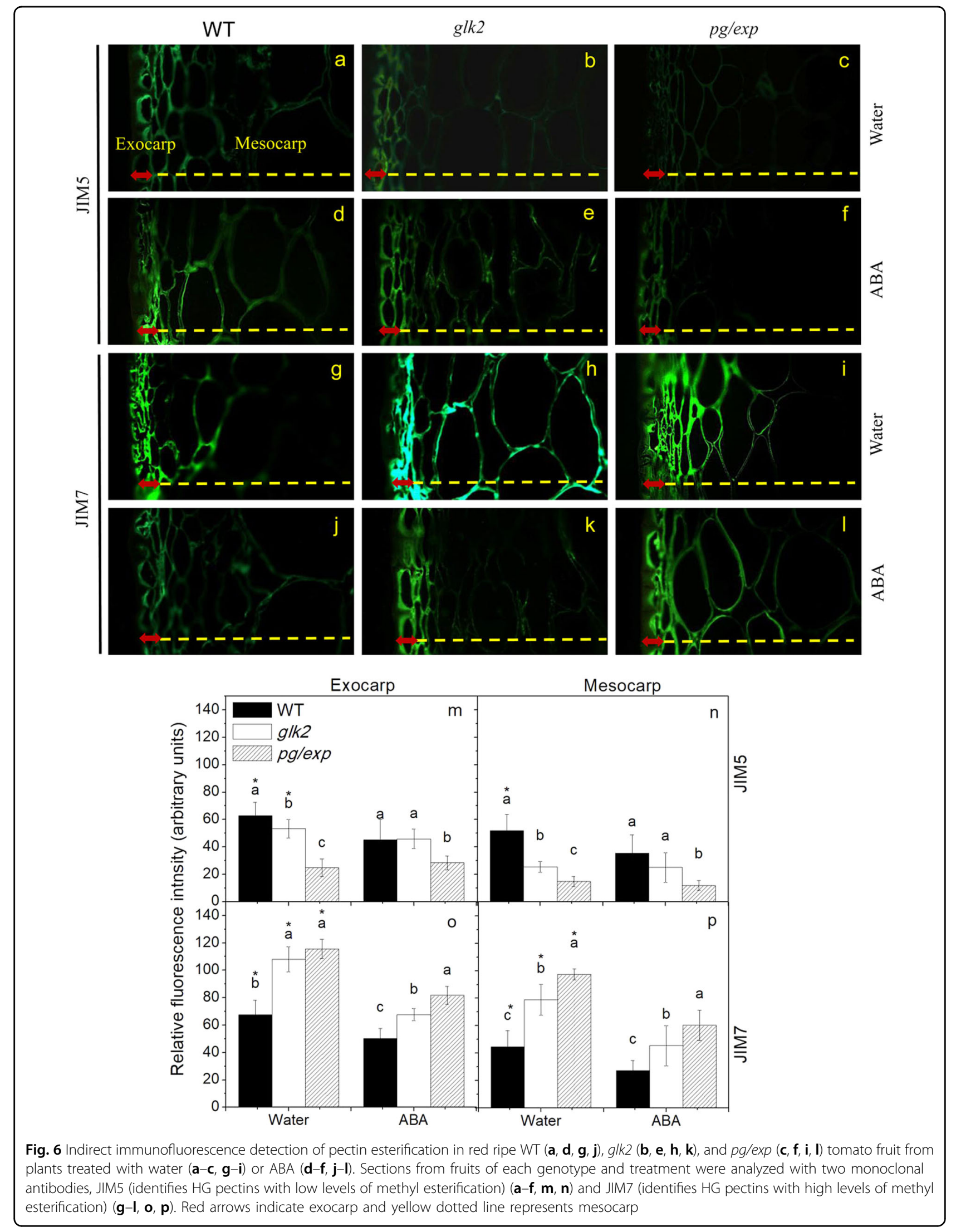



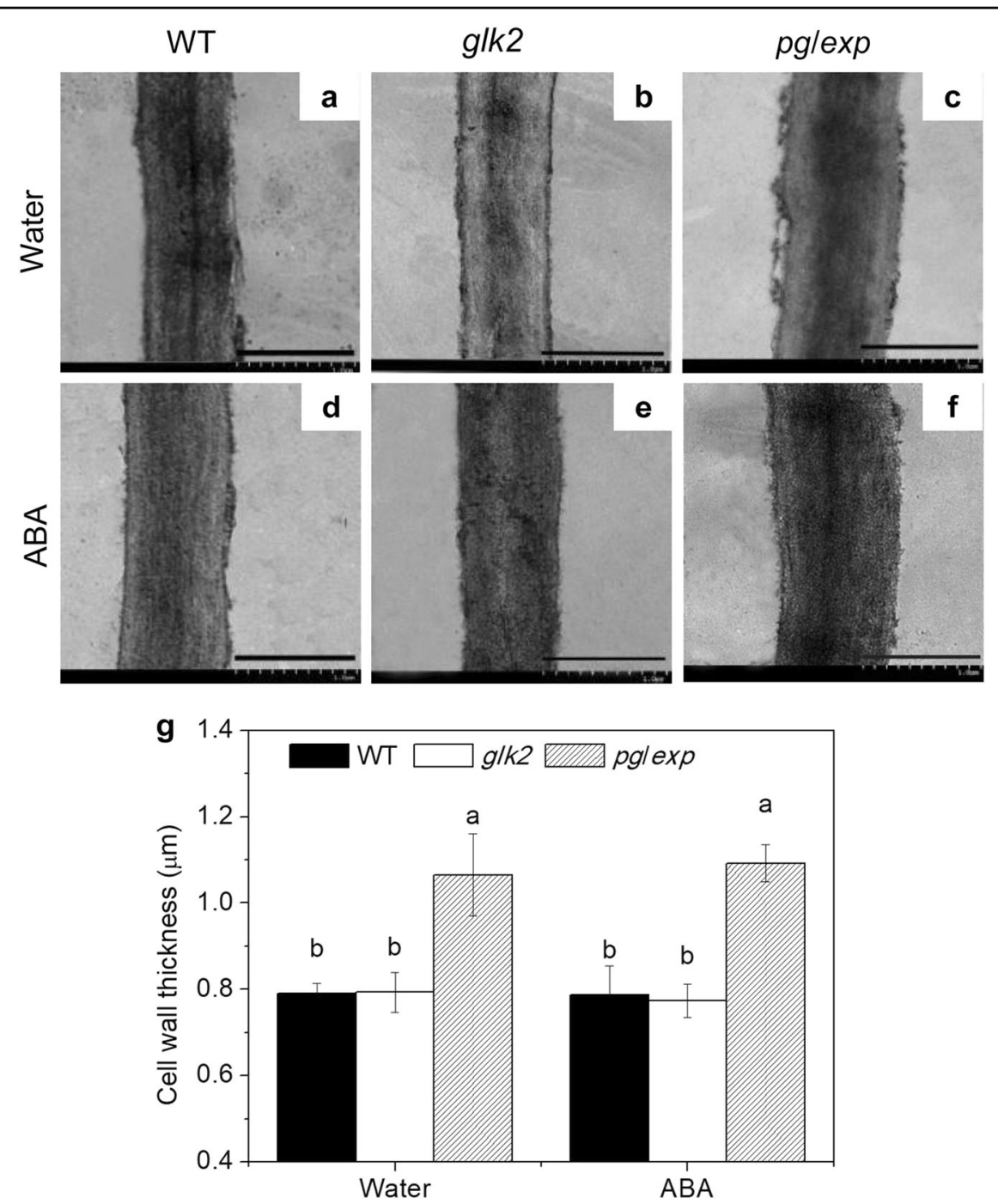

Fig. 7 Cell wall density (upper panels) and thickness (lower panels) observed by transmission electron microscopy examination of red ripe WT, $g / k 2$ and $p g / \exp$ tomato fruit from plants treated with water or ABA. Bar in each section equals $1.0 \mu \mathrm{m}$

significant differences in their tendency to crack when cracking was promoted by ABA application. The increase in cracking in response to ABA treatment was not observed in RR pg/exp fruit but was observed in WT and $g l k 2$ fruit. And there was no difference in cracking among the three genotypes when plants were treated with water.

ABA treatment also had an influence on tomato cell wall composition, resulting in lower amounts of WSP and SSP in mesocarp and blossom end tissues of all three genotypes. This does not appear to be related to influences on fruit ripening as no visible differences in ripening were observed and ABA is generally reported to enhance ripening, not slow ripening. The higher proportion of chelator soluble cell wall material (CDTA soluble, CSP) may be a response to the higher $\mathrm{Ca}^{2+}$ levels in the fruit due to the higher xylemic flow, but it is unclear what role if any this played in the increased cracking of ABA treated fruit.

Cell walls from $p g / \exp$ fruit also appeared thicker and denser than cell walls from WT fruit under electron microscopy, perhaps because of reduced disassembly of the cell wall polysaccharide polymer network. This difference could be another reason for resistance to cracking in this genotype. The thicker and denser cell walls from $p g / \exp$ fruit are reflected in the higher levels of CSP, SSP and cellulose in cell wall extracts prepared from the mesocarp of $p g / \exp$ fruit. Cantu ${ }^{46}$ previously demonstrated that the reduction of both PG and EXP activities resulted in isolated and in situ cell walls that swelled much less than walls from WT fruit that soften 

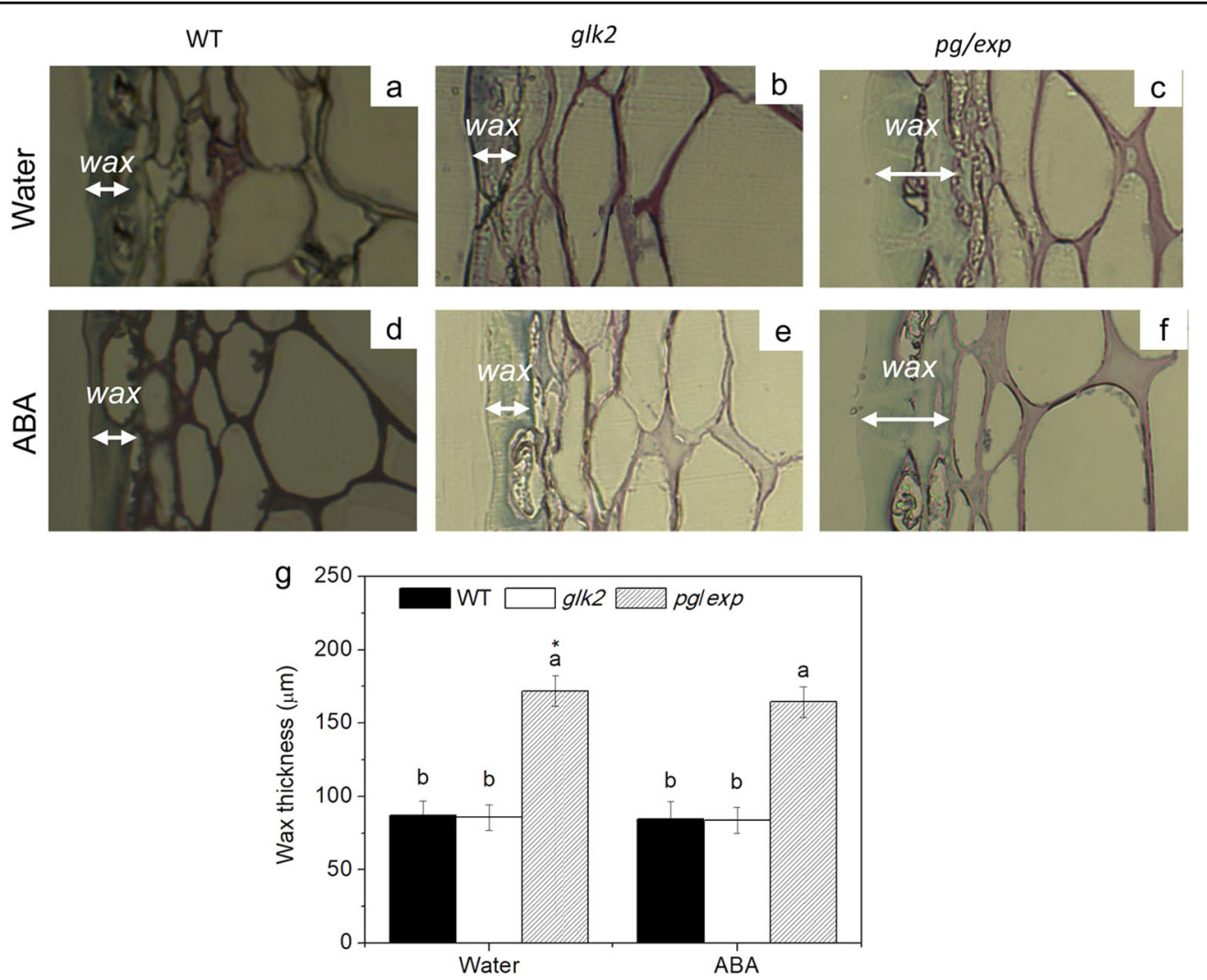

Fig. 8 Microscopic inspection of the cuticles of red ripe tomato fruit from WT, $g / k 2$, and pg/exp fruit from plants treated with water or ABA. Microscopy was used to detect epidermal waxes which were stained with toluidine blue O. The white arrows indicate the thickness of the wax

Table 3 The correlation coefficients between crack rate and relevant index

\begin{tabular}{|c|c|c|c|c|c|c|c|c|c|c|c|c|}
\hline & MG-TSS & RR-TSS & RC-TSS & MG-TA & RR-TA & RC-TA & SC1 & SC2 & CW-thickness & Wax-thickness & & \\
\hline \multirow[t]{2}{*}{ Crack rate } & $-0.509^{\mathrm{a}}$ & $-0.614^{b}$ & $-0.472^{\mathrm{a}}$ & -0.391 & $-0.516^{\mathrm{b}}$ & 0.135 & $-0.589^{\mathrm{a}}$ & $-0.582^{\mathrm{a}}$ & $-0.482^{\mathrm{a}}$ & $-0.497^{\mathrm{a}}$ & & \\
\hline & MG-firmness & RR-firmness & Fruit- $\mathrm{Ca}^{2+}$ & $\mathrm{CW}-\mathrm{Ca}^{2+}$ & Ex-cellulose & Me-cellulose & Pe-cellulose & Bl-cellulose & Ex-JIM5P & Me-JIM5P & Ex-JIM7P & Me-JIM7P \\
\hline \multirow[t]{2}{*}{ Crack rate } & -0.283 & -0.047 & 0.452 & 0.293 & $0.491^{\mathrm{a}}$ & -0.367 & $0.724^{b}$ & $-0.495^{\mathrm{a}}$ & 0.121 & 0.291 & $-0.547^{b}$ & $-0.569^{b}$ \\
\hline & Ex-WSP & Ex-CSP & Ex-SSP & Ex-SUMP & Me-WSP & Me-CSP & Me-SSP & Me-SUMP & & & & \\
\hline \multirow[t]{2}{*}{ Crack rate } & 0.166 & -0.239 & -0.393 & -0.348 & -0.43 & -0.263 & $-0.477^{b}$ & $-0.583^{\mathrm{a}}$ & & & & \\
\hline & Pe-WSP & Pe-CSP & Pe-SSP & Pe-SUMP & BI-WSP & BI-CSP & BI-SSP & BI-SUMP & & & & \\
\hline Crack rate & 0.334 & $-0.573^{\mathrm{a}}$ & 0.432 & -0.099 & -0.458 & 0.026 & -0.325 & -0.433 & & & & \\
\hline
\end{tabular}

MG-, RR- represent different maturation periods. MG mature green, $R R$ red ripe; $R C$ red ripe cracked fruit, Ex-, Me-, Pe-, BI- represent different parts of the fruit. Ex exocarp, Me mesocarp, Pe peduncle, BI blossom-end, CW cell wall, TSS total soluble solids, TA titratable acidity, SC1 stomatal conductance during the first week, SC2 stomatal conductance during the second week; WSP, CSP, SSP and SUMP indicate water, CDTA, and $\mathrm{Na}_{2} \mathrm{CO}_{3}$-solubilized pectin and the sum of pectin, respectively; JIM5P = Homogalacturonan (HG) pectins with low levels of methyl esterification; JIM7P represents HG pectins with high levels of methyl esterification

andicates significant correlation $(P$ values $<0.05)$

${ }^{b}$ Indicates highly significant correlation $(P$ values $<0.01)$

significantly at the fully ripe stage; which supports the conclusion that $p g / \exp$ fruit has a more intact cell wall than WT fruit. In our experiments, $p g / \exp$ had a thicker and denser cell wall that may resist swelling.

The cuticular wax layer was thicker in $p g / \exp$ fruit, which could also contribute to resistance to cracking. While waxes are part of the overall extracellular matrix, they are not targets of either PG or EXP, which suggests that suppression of the ripening-associated SIPG and
SlEXP1 genes may also have impacts on other structures at the fruit surface. It is interesting to note that in addition to changing cell wall network integrity, tomato fruit cuticle chemistry, and structure have been identified as fruit factors that influence ripening-associated fruit softening ${ }^{50}$.

The correlation analysis also showed that cracking rate was significantly associated with cell wall composition (protopectin and cellulose) and cell wall-thickness, as well 


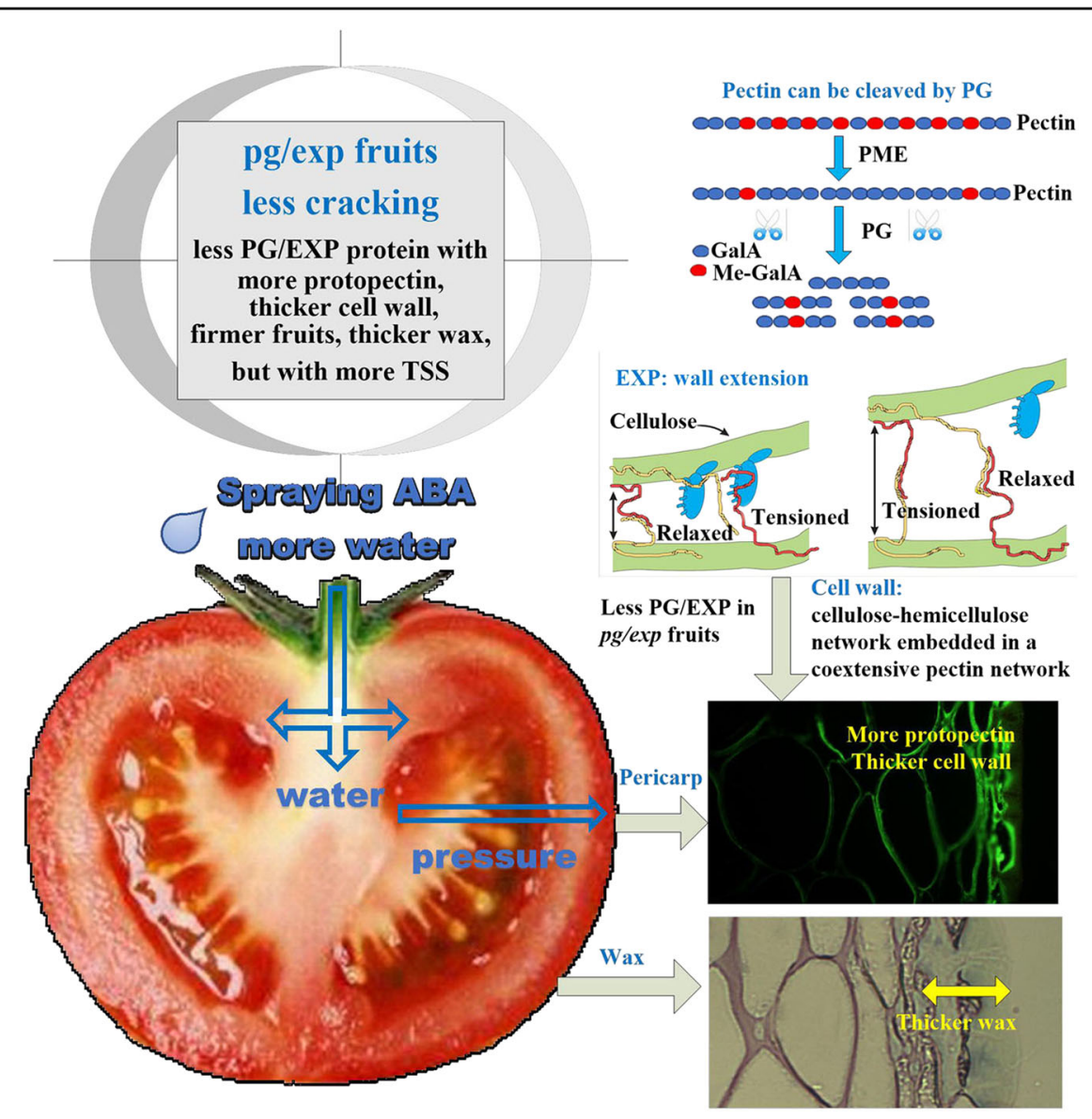

Fig. 9 Mechanism of ABA treated pg/exp fruit showing less cracking. pg/exp indicates transgenic fruit with suppressed SIPG and SIEXP1 expression. ABA treatment of tomato plants was used to increase water flow into fruit. However pg/exp fruit showed less cracking than wild type due to less polygalacturonase (SIPG) and expansin (SIEXP1) proteins in fruits. PG and EXP can cooperatively disassemble tomato fruit cell walls. With decreased PG and EXP proteins, pg/exp fruit are more firm, have more protopectin, thicker cell walls, and a thicker wax layer, but have more TSS and have less cracking in red ripe fruits

as with wax-thickness. Since increased water uptake by the fruit due to exposure of the plants to ABA promotes cracking, the physical constraints of the more intact cell walls in the $p g / \exp$ fruit seem to be the major factor providing resistance to cracking at the later stage of ripening (RR).

\section{Conclusion}

Ripening-related disassembly of the fruit cell wall, but not elimination of SIGLK2, influenced tomato fruit cracking. The simultaneous suppression of SIPG and SIEXP1 in ripening fruits reduced cell wall disassembly; $p g / \exp$ fruit were more firm, had more protopectin, thicker cell walls and wax, but with more TSS (Fig. 9). We conclude that a ripe fruit with more intact pectins in its primary walls is likely to resist cracking more effectively, as long as a reasonable degree of pectin-pectin bonding (via $\mathrm{Ca}^{2+}$ or other cross-linkages) is retained. The correlation analysis demonstrated that crack rate was associated most significantly with protopectin and cellulose content, rather than $\mathrm{Ca}^{2+}$, which confirms this view. The complexity of the fruit cell wall and its disassembly provides multiple opportunities to improve ripe fruit characteristics, including limiting losses due to cracking during ripening, handling, and distribution.

\section{Acknowledgements}

This work was partially supported by National Natural Science Foundation of China (31701924), the National Science Foundation (US IOS 0957264),

Fundamental Research Funds for the Central Universities, China (KYZ201609) and the US NSF support to ALTP (IOS 0544504 and 0957264). We thank the Electron Microscopy Laboratory and Profs. Judy Jernstedt and Ken Shackel of the Department of Plant Sciences, University of California, Davis, and Prof. Qiang Sun of the Department of Biology, University of Wisconsin, Stevens Point for their assistance.

\section{Author details}

'Department of Horticulture, Nanjing Agricultural University, Nanjing 210095, China. '2Department of Plant Sciences, University of California, Davis 95616, USA. ${ }^{3}$ Gangwon Agricultural Research and Extension Services, Chuncheon 200150, South Korea. ${ }^{4}$ Institute of Vegetables, Xinjiang Academy of Agricultural 
Sciences, 830091 Urumchi, China. ${ }^{5}$ College of Environmental and Resource Sciences, Zhejiang University, 310058 Hangzhou, China

\section{Author contributions}

J.F. designed the experiments and conducted the physiological and cell wall analysis in 2013; L.A., J.S., and F.S. conducted the experiments in 2012; Y.Q. performed cell wall analysis; W.Z. and L.J. provided suggestions for the experiments and edited the manuscript; T.S. conducted the immunofluorescence assay; P.A. and M.E. designed the experiments, guided the analysis, and edited the manuscript.

\section{Conflict of interest}

The authors declare that they have no conflict of interest.

\section{Publisher's note}

Springer Nature remains neutral with regard to jurisdictional claims in published maps and institutional affiliations.

Received: 23 June 2018 Revised: 7 October 2018 Accepted: 14 October 2018 Published online: 01 February 2019

\section{References}

1. Khadivi-Khub, A. Physiological and genetic factors influencing fruit cracking. Acta Physiol. Plant 37, https://doi.org/10.1007/s11738-014-1718-2 (2014).

2. Peet, M. M. Fruit cracking in tomato. HortTechnology 2, 216-223 (1992).

3. Balbontin, C. et al. Cracking in sweet cherries: a comprehensive review from a physiological, molecular, and genomic perspective. Chil. J. Agr. Res 73, 66-72 (2013).

4. Hahn, F. Fuzzy controller decreases tomato cracking in greenhouses. Comput. Electron Agr. 77, 21-27 (2011).

5. Khanal, B. P., Grimm, E. \& Knoche, M. Fruit growth, cuticle deposition, water uptake, and fruit cracking in jostaberry, gooseberry, and black currant. Sci. Hortic. Amst. 128, 289-296 (2011)

6. Huang, X. M. et al. Spraying calcium is not an effective way to increase structural calcium in litchi pericarp. Sci. Hortic.Amst. 117, 39-44 (2008).

7. Zoffoli, J. P., Latorre, B. A. \& Naranjo, P. Hairline, a postharvest cracking disorder in table grapes induced by sulfur dioxide. Postharvest Biol. Technol. 47, 90-97 (2008).

8. Thompson, D. S. Extensiometric determination of the rheological properties of the epidermis of growing tomato fruit. J. Exp. Bot. 52, 1291-1301 (2001).

9. Wiedemann, P. \& Neinhuis, C. Biomechanics of isolated plant cuticles. Plant Biol. 111, 28-34 (1998).

10. Sekse, L. Fruit cracking in sweet cherries (Prunus-Avium L) - some physiologicalaspects - a mini review. Sci. Hortic.-Amst. 63, 135-141 (1995).

11. Bargel, H. \& Neinhuis, C. Tomato (Lycopersicon esculentum Mill.) fruit growth and ripening as related to the biomechanical properties of fruit skin and isolated cuticle. J. Exp. Bot. 56, 1049-1060 (2005).

12. Matas, A. J., Cobb, E. D., Paolillo, D. J. \& Niklas, K. J. Crack resistance in cherry tomato fruit correlates with correlates with cuticular membrane thickness. Hortscience 39, 1354-1358 (2004).

13. Emmons, C. L. W. \& Scott, J. W. Environmental and physiological effects on cuticle cracking in tomato. J. Am. Soc. Hortic. Sci. 122, 797-801 (1997).

14. Emmons, C. L. W. \& Scott, J. W. Ultrastructural and anatomical factors associated with resistance to cuticle cracking in tomato (Lycopersicon esculentum Mill.). Int J. Plant Sci. 159, 14-22 (1998).

15. Moctezuma, E., Smith, D. L. \& Gross, K. C. Antisense suppression of a betagalactosidase gene (TBG6) in tomato increases fruit cracking. J. Exp. Bot. 54, 2025-2033 (2003).

16. Cao, Y., Tang, X. F., Giovannoni, J., Xiao, F. M. \& Liu, Y. S. Functional characterization of a tomato COBRA-like gene functioning in fruit development and ripening. BMC Plant Biol. 12, Artn 21110.1186/1471-2229-12-211 (2012).

17. Ackley, W. B. \& Krueger, W. H. Overhead irrigation water quality and the cracking of sweet cherries. HortScience 15, 289-290 (1980).

18. Dominguez, E. et al. Tomato fruit continues growing while ripening, affecting cuticle properties and cracking. Physiol. Plant. 146, 473-486 (2012).
19. Michailidis, M. et al. Metabolomic and physico-chemical approach unravel dynamic regulation of calcium in sweet cherry fruit physiology. Plant Physiol. Biochem 116, 68-79 (2017).

20. Belge, B., Goulao, L. F., Comabella, E., Graell, J. \& Lara, I. Refrigerated storage and calcium dips of ripe 'Celeste' sweet cherry fruit: combined effects on cell wall metabolism. Sci. Hortic. Amst. 219, 182-190 (2017).

21. Knoche, M. \& Peschel, S. Gibberellins increase cuticle deposition in developing tomato fruit. Plant Growth Regul. 51, 1-10 (2007).

22. Byers, R. E., Carbaugh, D. H. \& Presley, C. N. Stayman fruit cracking as affected by surfactants, plant-growth regulators, and other chemicals. J. Am. Soc. Hortic. Sci. 115, 405-411 (1990).

23. de Freitas, S. T., Shackel, K. A. \& Mitcham, E. J. Abscisic acid triggers whole-plant and fruit-specific mechanisms to increase fruit calcium uptake and prevent blossom end rot development in tomato fruit. J. Exp. Bot. 62, 2645-2656 (2011).

24. Koyama, K., Sadamatsu, K. \& Goto-Yamamoto, N. Abscisic acid stimulated ripening and gene expression in berry skins of the Cabernet Sauvignon grape. Funct. Integr. Genom. 10, 367-381 (2010).

25. Powell, A. L. T. et al. Uniform ripening encodes a golden 2-like rtanscription factor regulating tomato fruit chloroplast development. Science 336, 1711-1715 (2012).

26. Nguyen, C. V. et al. Tomato GOLDEN2-LIKE transcription factors reveal molecular gradients that function during fruit development and ripening. Plant Cell 26, 585-601 (2014)

27. Powell, A. L. T., Kalamaki, M. S., Kurien, P. A., Gurrieri, S. \& Bennett, A. B. Simultaneous transgenic suppression of LePG and LeExp1 influences fruit texture and juice viscosity in a fresh market tomato variety. J. Agric. Food Chem. 51, 7450-7455 (2003).

28. Vicente, A. R., Powell, A., Greve, L. C. \& Labavitch, J. M. Cell wall disassembly events in boysenberry (Rubus idaeus L. x Rubus ursinus Cham. \& Schldl.) fruit development. Funct. Plant Biol. 34, 614-623 (2007).

29. Akpinar-bayizit, A., Turan, M. A., Yilmaz-ersan, L. \& Taban, N. Inductively coupled plasma optical-emission spectroscopy determination of major and minor elements in vinegar. Not. Bot. Hort. Agrobot. Cluj. 38, 64-68 (2010).

30. Mollet, J. C., Park, S. Y., Nothnagel, E. A., \& Lord, E. M. A lily stylar pectin is necessary for pollen tube adhesion to an in vitro stylar matrix. Plant Cell, 12 1737-1749 (2000)

31. Sun, Q., Greve, L. C. \& Labavitch, J. M. Polysaccharide compositions of intervessel pit membranes contribute to Pierce's disease resistance of grapevines. Plant Physiol. 155, 1976-1987 (2011).

32. Zhang, Q. et al. Phosphatidic acid regulates microtubule organization by interacting with MAP65-1 in response to salt stress in Arabidopsis. Plant Cell 24, 4555-4576 (2012).

33. Knox, J. P. The use of antibodies to study the architecture and developmental regulation of plant cell walls. Int. Rev. Cytol. 171, 79-120 (1997).

34. Schuch, W. et al. Fruit-quality characteristics of transgenic tomato fruit with altered polygalacturonase activity. Hortscience 26, 1517-1520 (1991).

35. Kramer, M. et al. Postharvest evaluation of transgenic tomatoes with reduced levels of polygalacturonase: processing, firmness and disease resistance. Postharvest Biol. Technol. 1, 241-255 (1992).

36. Capel, C. et al. Multi-environment QTL mapping reveals genetic architecture of fruit cracking in a tomato RIL Solanum lycopersicum $\times$ S-pimpinellifolium population. Theor. Appl. Genet 130, 213-222 (2017).

37. Kasai, S., Hayama, H., Kashimura, Y., Kudo, S. \& Osanai, Y. Relationship between fruit cracking and expression of the expansin gene MdEXPA3 in 'Fuji' apples (Malus domestica Borkh.). Sci. Hortic. Amst. 116, 194-198 (2008).

38. Brummell, D. A. et al. Modification of expansin protein abundance in tomato fruit alters softening and cell wall polymer metabolism during ripening. Plant Cell 11, 2203-2216 (1999).

39. Huang, X. M. et al. Cell wall modifications in the pericarp of litchi (Litchi chinensis Sonn.) cultivars that differ in their resistance to cracking. J. Hortic. Sci. Biotechnol. 81, 231-237 (2006).

40. Yong, W., Lu, W. J., Li, J. G. \& Jiang, Y. M. Differential expression of two expansin genes in developing fruit of cracking-susceptible and -resistant litchi cultivars. J. Am. Soc. Hortic. Sci. 131, 118-121 (2006).

41. Marondedze, C., Gehring, C. \& Thomas, L. Dynamic changes in the date palm fruit proteome during development and ripening. Hortic. Res. 1, 14039 (2014).

42. Shi, Y., Jiang, L., Zhang, L., Kang, R. \& Yu, Z. Dynamic changes in proteins during apple (Malus $x$ domestica) fruit ripening and storage. Hortic. Res. 1, 6 (2014).

43. Somerville, C. et al. Toward a systems approach to understanding plant-cell walls. Science 306, 2206-2211 (2004). 
44. Dellapenna, D., Alexander, D. C. \& Bennett, A. B. Molecular-cloning of tomato fruit polygalacturonase - analysis of polygalacturonase messenger-rna levels during ripening. Proc. Natl Acad. Sci. USA 83, 6420-6424 (1986).

45. Gross, K. C. \& Wallner, S. J. Degradation of cell wall polysaccharides during tomato fruit ripening. Plant Physiol. 63, 117-120 (1979).

46. Cantu, D. et al. The intersection between cell wall disassembly, ripening, and fruit susceptibility to Botrytis cinerea. Proc. Natl Acad. Sci. USA 105, 859-864 (2008).
47. Braccini, I. \& Perez, S. Molecular basis of $\mathrm{C}^{(2+)}$-induced gelation in alginates and pectins: the egg-box model revisited. Biomacromolecules 2, 1089-1096 (2001).

48. Wang, N. \& Qin, X. N. Effect of mineral nutrition levels on fruit splitting in JinCheng orange. J. Southwest Agric. Univ. 4, 458-462 (1987).

49. Verslues, P. E. \& Zhu, J. K. New developments in abscisic acid perception and metabolism. Curr. Opin. Plant Biol. 10, 447-452 (2007).

50. Saladie, M. et al. A reevaluation of the key factors that influence tomato fruit softening and integrity. Plant Physiol. 144, 1012-1028 (2007). 